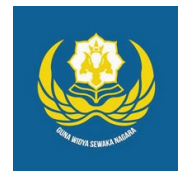

Jurnal Analogi Hukum

Journal Homepage: https://ejournal.warmadewa.ac.id/index.php/analogihukum

\title{
Kedudukan Pengemban Jabatan Legal Officer dalam Menjamin Aktivitas Suatu Perseroan Terbatas
}

\author{
I Made Yuda Suarmagita*, Ni Luh Made Mahendrawati dan I Gusti Ketut Sri Astiti \\ Fakultas Hukum, Universitas Warmadewa, Denpasar, Bali-Indonesia \\ *madeyuda16@gmail.com
}

\begin{abstract}
How To Cite:
Suarmagita, I. M. Y., mahendrawati, N. L. M., \& Astiti, I. G. K. S. (2021). Kedudukan Pengemban Jabatan Legal Officer dalam Menjamin Aktivitas Suatu Perseroan Terbatas. Jurnal Analogi Hukum. 3 (2). 210-214. Doi: https://doi.org/10.22225/ah.3.2.2021.210-214

Abstract-A legal officer is a profession whose job is to take care of all documents, permits, and legal issues that occur within the company. This thesis raises problem formulations, namely How do you assume a legal officer position in guaranteeing the activities of a limited liability company?. How do you assume a legal officer position in guaranteeing the activities of a limited liability company? The research method used is Juridical-Normative. The research used by the author is a statutory approach, a conceptual approach, a case approach, an analytical approach, and a philosophical approach. The technique used is document study or literature study. The results of this study indicate that the position of the Legal Officer in the company is directly under the Board of Directors, given the function of the Legal officer in running a company to manage company documents which include documents, permits, documents, and legal steps that must be taken. taken if there are legal problems for both civil and criminal matters. The legal officer is also authorized to make adjustments to new regulations issued by the government relating to company operations, so that the legality of the company is still recognized by the government.
\end{abstract}

Keywords: Legal Officer; Responsibility Limited Company.

\begin{abstract}
Abstrak-Pengemban jabatan Legal Officer adalah suatu profesi yang tugasnya mengatur dokumennya, perizinannya, dan masalah hukum terjadi pada perusahaan. Skripsi ini mengambil rumusan masalah, yaitu Bagaimana pengemban jabatan legal officer dalam menjamin aktivitas suatu perseroan terbatas?Bagaimana pengemban jabatan legal officer dalam menjamin aktivitas suatu perseroan terbatas?Metode Penelitian yang digunakan adalah Yuridis-Normatif.Pendekatan Penelitian Adalah pendekatan perundangan, konseptual, kasus, analisis, serta pendekatan filosofis. Teknik yang dipakai ialah studi dokumen ataupun studi kepustakaan. Hasil penelitian ini menunjukan bahwa Kedudukan Legal Officer dalam perusahaan berada langsung dibawah Direksi, merujuk pada fungsi dari Legal officer saat menjalankan suatu perusahaan melakukan pengurusan surat-surat perusahaan yang meliputi dokumen-dokumennya, perizinan-perizinannya, surat- suratnya, dan langkah-langkah hukumnya yang sebaiknya ditempuh kalau adanya permasalahan hukum baik untuk masalah perdata maupun pidana. Legal officer tentu bertugas untuk penyesuaian terhadap aturan baru yang diterbitkan oleh pemerintah yang ada kaitan dengan operasional perusahaan, supaya legalitas dari perusahaan tetap dapat pengakuan oleh pemerintah.
\end{abstract}

Kata Kunci: Pengemban Jabatan Legal Officer; Tanggung Jawab Perseroan Terbatas.

\section{Pendahuluan}

Perseroan terbatas ketika badan hukum tak menyangkut harta sendiri pemegang saham selain ditunjukan beda oleh perundangan ataupun aturannya. Dari perundangan Nomor 40 tahun 2007 mengenai Perseroan Terbatas (UUPT), pada suatu perusahaan dapat Organ Perseroannya yang mana pengaturannya pada UU PT ialah Rapat Umum Pemegang Sahamnya, Direksinya, serta Dewan
Komisarisnya. Selain itu perseroan juga punya banyak bagian di sebuah sistem keanggotaan, bagian termasuk sebagaimana umumnya adalah personalia division, accounting, marketing, maintenance, public relation, and legal division. Bagian yang amat mirip dari ilmu hukum adalah legal division yang mana ialah seorang yang kerja dalam legal division di beri nama yaitu jabatan Legal Officer.

Kedudukannya Legal Officer untuk 
pengemban keterampilan di berbagai hukum dengan beberapa perseroan terbatas dewasa ini, tengah bangun ketika maju cukup cepat. Legal Officer punya peran yang begitu berarti dalam suatu perseroan terbatas. Legal Officer memperhatikan semua dokumennya, perizinannya, dan problem hukumnya yang ada dalam perusahaan. Dengan tidak ada dokumen dan perizinan, perusahaan tak harap akan berjalan. ataupun juga jika terbentuk masalah hukum, semua perusahaan pasti akan begitu banyak hambatan. Pengemban jabatan Legal Officer, di dalam perseroan terbatas punya kerjaan serta fungsi.

Kegunaan yang pegang Jabatan Legal Officer dalam perseroan terbatas mendorong perbuatan pebisnis perseroan terbatas serta menjaga investasi juga menjaga aset perusahaan. Pekerjaan legal officer bermacam terurai bagi perusahaannya. Yang kemudian ini dibeberkan cepat contoh masing-masing pekerjaan dari legal officer bank dan perusahaan pembiayaan, perusahaan ekspedisi, perusahaan minyak juga gas alam (migas), perusahaan pemasukan modal asing, perusahaan industri (termasuk perusahaan industri media) (Sudaryat, 2013).

Pekerjaan legal officer di macam-macam perusahaan, boleh dijadikan bahwa tugas legal officer Legal Officer kerja menjaga semua dokumennya, perizinannya, serta masalah hukumnya yang berlakunya dalam perusahaan. Tak dengan dokumen dan perizinan, perusahaan tak dapat akan berjalan. Begitu juga jika terjadi masalah hukum, operasional perusahaannya pastinya sangat terganggu (Sudaryat, 2013).

Dalam menjalankan tugasnya legal officer juga menjadi penasehat hukum perusahaan, semua masukan yang diberikan oleh orang pengurus pekerjaan legal officer amat dampaknya dari kepastian Direkturnya. Di sebelah lain, legal officer juga bikin dokumen hukum seperti buat janji antara pembeli dan perusahaan. maka timbul masalah di petugas jabatan legal officer dan lain masukan yang keluar oleh legal officer nyata salah dan timbul rugi bagi perusahaan. saat seorang petugas jabatan legal officer salah saat bikin dokumen hukum serta metiadakan suatu dokumen hukumnya.

Menurut bagian di atas, maka harus lihat apa tugas dari legal officer dapat dikelompokan jadi profesi dan bila lihat pada tugas dalam perusahaannya bisakah pemegang jabatan legal officer tanggung jawab pada hukumnya saat jalankan tugas serta wewenang. ini dituju untuk membesarkan tugas jabatannya legal officer serta serahkan kenyataan hukum buat tugas jabatan legal officer dalam melakukan tugas serta wewenang.

\section{Rumusan Masalah}

Adapun rumusan masalahnya:

1. Bagaimana pengemban jabatan legal officer dalam menjamin aktivitas suatu perseroan terbatas?

2. Bagaimana pengemban jabatan legal officer dalam menjamin aktivitas suatu perseroan terbatas?

\section{Metode}

Penelitiannya menggunakan metode penyelidikan Yuridis-Normatif. Pendekatannya di Penelitianya dipakai oleh penulis ialah perundangan, gagasan, kasus, analisis, dan filosofis. Caranya dipakai ialah studi dokumen ataupun studi pustaka. Cara kumpul bahan hukumnya dilakukannya dengan prosedur inventarisasi lalu cara belajar dan mengukur bahan hukum primer, sekunder dan tersier yang kaitanya pada penelitian ini.

Penelitiannya ditujukan untuk cermati yaitu tugas jabatan legal officer dalam menjamin aktivitas suatu perseroan terbatas serta bentuk tanggung jawab legal officer dalam tugas-tugasnya.

\section{Hasil dan Pembahasan}

\section{Pengemban Jabatan Legal Officer Dalam Menjamin Aktivitas Suatu Perseroan Terbatas}

Peran legal officer di perusahaan sangatlah beragam, mulai dari mengawasinya, memonitoringnya, menyelesaikan masalahnya dan memberi pendapat hukumnya. Secara garis besar peran dari legal officer antara lain:

Secara internal, legal officer punya bagian fungsional yang cukup berarti karena umumnya tempatnya langsung dibawah direksi, dengan gampangnya legal officer membuat hubungan dengan bagian lainnya pada perusahaan, misal bagian personalianya, marketingnya, ataupun bagian keuangan perusahaannya.

Secara eksternal, legal officer adalah penyambung kerjasama antar perusahaan dengan pihak tidak di perusahaan, baik pemerintah maupun swasta. Untuk pastikan perizinan perusahaannya cukup, legal officer akan buat daftar perizinannya itu dan siapkan konsep ajukan ke instansi pemerintah. Untuk pastikan tugas sama perusahaannya sama pihak 
swasta, misal mitra bisnis atau vendor, legal officernya harus siapkan kontrak tugas sama dan mengawasinya. Tugas eksternalnya ini, dalam umum perlu hampir semua keterampilan hukum seorang legal officernya Bentuk konsep suratnya, kontraknya, dan legal opininya.

legal officer tugasnya buat perusahaan yang jumlahnya besar, bisa dibagi jadi banyak bagian, misal legal officernya yang harus tugas mengawasi dokumennya serta perijinannya ataupun legal officernya yang mengawasi permasalahan hukumnya, baik itu masalahnya perdata maupun pidana. tapi di perusahaan menengah, legal officernya menangani semua halnya, baik itu dokumennya ataupun masalah hukumnya (Sembiring, 2009).

Hal minat lain jadi kewenangan legal officernya ialah selesaikan semua masalah hukum yang terjadi. Penyudahan masalah hukum yang terjadinya dapat dibuat lewat hubungan dengan instansi terkait ataupun dengan kantor hukumnya yang ulung, sama dengan masalah hukumnya yang terjadi (Sembiring, 2009).

Ingat begitu berarti pekerja bagian legal officer, maka tak semua orang yang bisa ditaruh pada posisi ini, tidaknya orang itu harus punya kualifikasi sebagai berikut:

Bisa bersikap, berperilaku serta kerja jujur. Kejujurannya sangat perlu supaya dia tidak tergoda untuk pakai jabatannya untuk dapat untung pribadi dan buat rugi perusahaan. Bisa kerjasama dalam tim. Kemampuan kerjasama dalam tim perlu untuk punya oleh orang yang ada di bagian legal ini karena dalam cara pengurusan legalitas, dia tak bisa kerja sendiri. Bisa pikirannya logis, obyektif serta jernih didasarkan fakta. Punya dasarnya pengetahuan hukum yang kuat juga menyangkut hukum perusahaannya. Lakukan legal research yang bisa berikan data guna siapkan masukan hukum bagi keperluan perusahaannya. Mampu analisa yang tajam tentang kondisi perusahaan dalam urusan dengan masalah hukumnya. Persuasi serta komunikasinya untuk bicara dan beri saran pada perusahaan apa yang harus dilakukannya. Tegas guna tentukan keputusannya, khususnya bila perusahaannya harus bertatapan dengan masalah hukum.

Jabatan Legal Officer untuk pengemban keahlian dibidang hukumnya pada suatu perseroan terbatas saat ini sedang berkebangnya cukup pesat. Perusahan yang besar misalnya perusahaan levelnya Perseroan Terbatas tentu saja akan mengalami permasalahan $=$ yang menghambat jalannya urusan perusahaannya.
Seorang Legal Officer yang akan turun tangan untuk mengatasinya segala hal yang menghalanginya urusan perusahaannya terutama masalah hukum yang terjadi pada perusahaannya.

\section{Pertanggungjawaban Pengemban Legal Officer Secara Hukum dalam Suatu Perseroan Terbatas}

Legal Officer adalah suatu pekerjaan yang diminta kualifikasinya dari lulusan Fakultas Hukum. Soal harus ataupun tidaknya legal officer adalah advokat, hal itu balik pada keperluannya serta kebijakannya perusahaan itu. Kamus Besar Bahasa Indonesia memberi pengertian Profesi saat bidang kerja yang dilandasi pendidikan keahlian (keterampilannya, kejuruannya dan sebagainya).

Pendapat Brandeis, guna bisa dikatakan sebagai profesinya, maka tugas itu sendiri harusnya mengamalkan adanya dukungan berupa:

Karakteristik pengetahuannya, Diawetkannya pada sibukan orang lain, Kesuksesannya tersebut tak dasari pada keuntungan finansialnya, Dukung oleh ada organisasinya, pekerjaannya serta organisasi profesinya itu antara lain tentunya semua ketentuannya misalnya ialah kode etik, serta pula tanggung jawabnya saat maju dan sebar kerjaan yang tepat (Tedjosaputro, 1995).

Pengemban jabatan Legal Officernya punya tugas tindakan legal due diligence/legal audit (catatan hukumnya) dan court clearance (surat bebas perkaranya) beri masukan hukumnya, siapkan dokumen hukumnya, adakan catatan hukumnya, menyudahi masalah hukumnya (jadi mediatornya), mengatur serta arsipkan dokumen hukumnya, untuk laporan mengenai progres pekerjaannya di bidang hukum, penasehat/pemberi masukan/ pertimbangan, wakil perusahaan/group perusahaan, representasi dari BOD (Board on Director)/pemilik perusahaannya.

Perusahaan adalah suatu fenomena pada hukum perusahaannya yang muncul sebagai reaksi kepada perlunya untuk tingkatkan efisiensi ekonomis pada kegiatan usahanya. berikutnya diperlukannya manakala suatu kelompok perusahaannya bergerak dalam berbagai jenis bisnis yang tidak saling terhubung pada suatu bentuk usaha tertentu yang dalam prakteknya lebih dikenalnya dengan konglomerasi (Assari, 2000). 
Ada sebagian faktor tugas suatu perusahan yang akan mengenai kegiatan bisnis, yang mana di antaranya ialah:

1. Inflasi, Inflasi bisa kita beri arti ialah indikator untuk melihat proses meningkatnya harga secara terus serta proses meningkatnya harga itu juga mempengaruhi hal yang lainnya.

2. Produktivitas, Produktivitas bisa kita beri arti ialah perbandingan antara bahan bakunya ataupun masukan produk ataupun luaran yang mana perbandingannya harusnya selalu di liat serta diatur supaya mencapai hasil yang kita mau.

3. Pemerintah, Pemerintah bosa di beri arti sekumpulan orang ataupun organisasi yang punya wewenang ataupun kuasa untuk buat ataupun menetapkannya suatu aturan ataupun hukum terhadapnya suatu permasalahannya.

Krida bisnis bisa kita jumpa lewat dua pendekatannya ialah: pertama pendekatannya yang utamanya kepentingan pemegang sahamnya serta yang kedua pendekatannya yang pakai perspektif pemangku kepentingannya atas dasarnya keadilan sosialnya (Adiprigandari \& Suprapto, 2006). pada perspektif utama, bisnisnya adalah kegiatan yang fokusnya pada maksimalnya untung dengan prinsip beli murah serta mahal jualnya.

Pada perspektif kedua, bisnisnya tak bisa lepas diri dari terkaitnya serta hubungannya antar berbagai pihak di masyarakat yang terkait pada kedatangan perusahaannya. Terkaitnya serta hubungannya itu pada waktu baik untuk dapat sumber dayanya untuk masukan yang diubah perusahaannya untuk beri nilai, maupun pihaknya yang terkait pada proses transformasinya perusahaan itu.

Tanggung jawab atas perbuatannya yg dibuat oleh seorang ada dua bentuknya, yaitu tanggung jawab cara perdata serta tanggung jawab cara pidana. Tanggung jawab perdata adalah berhubungannya dengan masalahnya di keperdataan, missal ganti rugi untuk ruginya yang timbul dari perbuatannya itu.

Bila dilihat dari pertinjauan hukum ikatannya, lalu tanggung jawabnya tugas kerjaan Legal Officernya ialah juga lihat dari sebuah ikatan hukum perdatanya di tengah pemakai tugas untuk pihak yang melayani (misal kliennya, pasiennya). kaitan hukumnya keperdataan yang terjadi guna pekerjanya serta guna jasanya, cara singkatnya bisa dilihat jadi dua model perikatannya. Model pertamanya ialah ikatan yang janjikan sesuatu hasilnya selagi model kedua ialah ikatan agar dijanjikannya satu perusahaannya (Shidarta, 2009).

Secara Perdata legal officer harusnya tahu dasarnya dari masalahnya yang akan dihadapinya oleh perusahaannya. misal masalah yang akan dihadapi oleh perusahaannya ialah perjanjian kerja (kontrak kerja) yang mana pada legal officer harusnya paham apa dasar dari perjanjian diantaranya adalah:

\section{1) Sepakat \\ 2) Cakap \\ 3) Hal tertentu \\ 4) Sebab yang halal.}

Diantara satu giat perusahaan yang diguna untuk memperoleh nilai perusahaan adalah melakukan kerjasama antar perusahaan lainnya. Adapun giat kerja sama antar perusahaan lain tentu buat berbagai ketentuannya serta perjanjiannya yang harus dibuat serta dipatuhinya oleh kedua belah pihak.

Suatu kegiatan ini, legal officernya punya peran pada pengurusan serta penyusunan surat perjanjian kerja samanya anta perusahaannya. Tugasnya tentu menuntut ketelitian legal officernya agar semua ketentuannya serta perjanjiannya antar perusahaannya terjalin dengan lengkap, rinci, serta tidak ambigu. Demikianlah perjanjiannya berjalan dengan lancar serta dalam jalan kerja samanya tak ada pihak yang rasa rugi.

\section{Simpulan}

Kedudukan Pengemban Jabatan Legal Officer pada perusahaan punya peran penting, mana posisi Legal Officernya secara fungsionalnya di bawah Direksi. Legal officer dalam hal jalan suatu perusahaan lakukan urusan surat-surat perusahaan yang liput dokumennya, perizinannya, suratnya dan langkah hukumnya yang harus dilewatinya jika ada masalah hukumnya baik untuk masalah perdata maupun pidana. Berdasarkan KUHPer dan perundangan No. 13 Tahun 2003 menganai tenaga kerjaa bahwa Legal Officernya bisa dibilang ialah profesi, tapi batasnya hanya profesi umum, Hubungan hukumnya yang terjadi antar tugasnya jabatan Legal Officernya serta perusahaannya ialah hubungan kerja karena di dasar oleh janji kerjanya.

Tanggung jawabnya dari seorang Legal Officer untuk Perseroan Terbatas ialah lindungi pentingnya perseroan yang bisa jadi ancaman bagi perseroannya, jaga aset perseroannya 
supaya perseroan bisa jalan pada masa waktunya yang lama, serta beri opini hukumnya pada perusahaannya. Legal officer juga punya wewenang buat penyesuai pada aturan baru baru yang keluar oleh pemerintah yang terkait pada jalan perusahaannya, supaya legalitasnya pada perusahaannya tetap diakuinya oleh pemerintah.

\section{Daftar Pustaka}

Adiprigandari, S., \& Suprapto, A. (2006). Pola Tanggung Jawab Sosial Perusahaan Lokal di Jakarta. Jurnal Filantropi dan Masyarakat Madani.

Assari, H. F. (2000). Peningkatan Kinerja BUMD Melalui Pengembangan Holding Company. Fakultas Sosial Politik Universitas Indonesia.

Sembiring, J. J. (2009). Panduan Mengelola Perizinan, Dokumen, HAKI, Ketenagakerjaan, dan Masalah Hukum Di Perusahaan, Cetakan Pertama. Jakarta: Transmedia Pustaka.

Shidarta. (2009). Moralitas Profesi Hukum. Bandung: Refika Aditama.

Tedjosaputro, L. (1995) Etika Profesi Notaris dalam penegakan hukum pidana. Yogyakarta: Bigraf Publishing. 